\title{
Exercise training session-induced metabolic acidosis in barrel racing horses
}

\author{
Cláudio Luís Nina Gomes ${ }^{1^{*}}$ AD Andressa Mendes Alves ${ }^{2}$ José Dantas Ribeiro Filho $^{3}$ \\ Felipe de Jesus Moraes Junior ${ }^{4}$ Ricardo de Macedo Chaves ${ }^{4}$ Rosany Maria Cunha Aranha ${ }^{5}$ \\ Rodrigo Santos Fucuta $^{6}$ Bruna Maria Ribeiro ${ }^{7}$
}

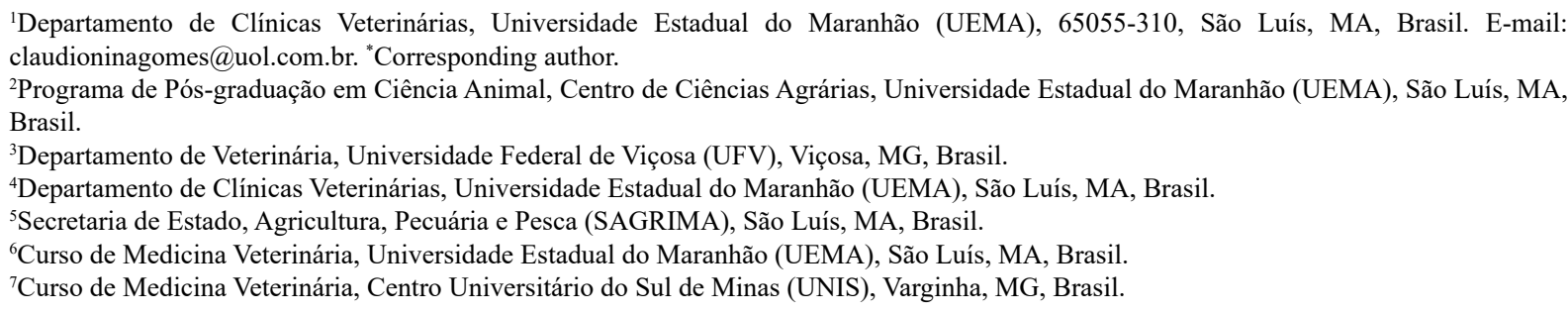

ABSTRACT: In horses, acid-base balance disorders are common after intense exercise, with metabolic acidosis being the most common after high intensity and short duration exercise. Understanding the processes that cause them is fundamental for procedures, which aimed to improve the physical fitness of horses for athletic purposes, with fewer changes in homeostasis. The present study assessed the effect of barrel racing on acid base balance in Quarter Horse, at the following times: T0 -immediately before training; T1 - immediately after the end of the second course; T2 - one hour after the end of the second course. In T1, there was decrease $(\mathrm{P}<0.05)$ in the $\mathrm{pH}_{1} \mathrm{HCO}_{3}^{-}, \mathrm{pCO}_{2}, \mathrm{cBase}, t \mathrm{CO}$, and strong ion difference concentrations, while the plasma lactate and anion gap increased $(P<0.05)$. It was concluded that barrel racing training caused transient metabolic acidosis in the horses, and hyperlactatemia was still present after an hour of rest.

Key words: horse, exercise, acidosis, lactate, barrel racing.

Acidose metabólica induzida por sessão de treinamento em equinos de tambor

RESUMO: As desordens no equilibrio ácido base são comuns em equinos após exercício intenso. Exercícios de alta intensidade e curta duração ocasionam frequentemente acidose metabólica. Entender as alterações neste equilibrio é essencial para instituir programas de treinamentos que visam melhorar o condicionamento físico dos equinos atletas, minimizando alterações na homeostasia. O estudo avaliou o efeito do treinamento de três tambores sobre o equilibrio ácido base em equinos. A avaliação foi realizada nos seguintes tempos: T0 imediatamente antes do início do treinamento; T1 - imediatamente após o fim do segundo percurso de treinamento; T2 - uma hora após o fim do segundo percurso. Em T1, ocorreu diminuição $(\mathrm{P}<0,05)$ nos valores do $\mathrm{pH}, \mathrm{HCO}_{3}^{-}$, pCO, cBase, tCO, e diferença de ions fortes, enquanto o lactato e o ânion gap aumentaram $(P<0,05)$. Conclui-se que o treinamento de três tambores causou acidose metabólica passageira nos equinos, sendo que a hiperlactatemia ainda permaneceu manifestada após uma hora de descanso.

Palavras-chave: equino, exercicio, acidose, lactato, tambor.

\section{INTRODUCTION}

Biochemical responses obtained in laboratory exams are an essential part of the assessment of a horse's physical conditioning. They indicate systemic alterations and energy expenditure of the animal according to the type of exercise performed in training or competitions (FERRAZ et al., 2010).

All exercise generates energy through the aerobic and anaerobic metabolic pathways. Exercise intensity and duration determine which is predominant (CAIADO et al., 2011). Equestrian tests, where the exercise of high intensity and short duration, that require rapid energy production and adequate energy consumption to meet the demand of the intense muscular activity, and because it cannot be provided sufficiently by the aerobic pathway, requires the anaerobic pathway (BARBOSA et al., 2016).

Anaerobic glycolysis is the main anaerobic energy production mechanism (BARBOSA et al., 2016), and during this occurs endogenous production of acid, mainly lactic acid. The disassociation of lactic acid generates hydrogen protons $\left(\mathrm{H}^{+}\right)$and lactate. Increase in $\mathrm{H}^{+}$concentration decreases the $\mathrm{pH}$ that, if excessive, can generate muscular fatigue and alter the body acid base balance (ABB) (BAYLY \& KLINE, 2007). Very commonly the term lactate is used in various literatures as a synonym for lactic acid. Within the physiological range of blood $(7.35$ to 7.45 ) and muscle (6.6 to 7.2$) \mathrm{pH}$, more than $99 \%$ 
of lactic acid is dissociated into lactate ion and hydrogen ion (FERGUSON et al., 2018). Therefore, the term lactate is commonly used instead of lactic acid because it is in this form that this substance is present in the body (DOS SANTOS, 2019). The increased lactate production coincides with cellular acidosis and remains a good indirect marker for cell metabolic conditions that induce metabolic acidosis. However, the terms "lactate" or "lactic acid" need to be removed from any association with the cause of acidosis (ROBERGS et al., 2019).

Alterations in $\mathrm{ABB}$ are directly related to exercise intensity and can be diagnosed in hemogasometry, blood lactate concentration, strong ion difference and anion gap examinations (CONSTABLE, 2000; SCHÜCK e MATOUSOVIC, 2005).

It has been reported that acidosis in athlete horses generated by high-intensity exercise is more intense in the first five minutes after the end of the activity, as the $\mathrm{ABB}$ returns to normality in the first hour after exercise (ROSE, 1987). It is important to verify whether this fact also occurs in horses that perform high intensity and short duration exercise in different equestrian sports in which the tests are over short courses, including barrel racing, balize and vaquejada, in the different regions of Brazil.

The barrel racing modality is well-known in the Brazilian regions, being very often practiced in the Northeast, where hot and humid climate prevails. The equine race considered ideal for this equestrian mode is the Quarter Horse, which develops high speed in short distances and rapid acceleration, deceleration and change of direction (STRICKLIN, 1997; NIELSEN \& LUKASKI, 2006; SILVA et al., 2013), and has a good proportion of type IIX muscle fibers, that have low oxidative capacity and high glycolytic capacity, important for intense exercise in a short time (LINDINGER, 2004).

The regulation of the barrel racing authorizes the use of the same horse to carry out up to two courses in the race, which favors to avoid overload of effort to the animal. However, a high production of high lactic acid during physical exertion can imbalance the base acid balance and possibly one hour of rest is not enough to recompose this balance. Therefore, the evaluation of these animals under training and in the barrel racing tests is useful to verify: What is the ABB level in horses after two three-drum courses? Is one hour of rest sufficient for balance recomposition? The present study aimed to answer these questions.

\section{MATERIALS AND METHODS}

The experiment was carried out at the Quatro Irmãos Horse Riding, located in the municipality of Raposa, latitude: -6.51667 . longitude: $-44.18336^{\circ} 31^{\prime} 0^{\prime \prime}$ South, state of Maranhão, Brazil. The horses' daily diet consisted of bulk: Tifton 85 hay $(2 \%$ of the bodyweight of the horse), divided in two supplies a day at 9 a.m. and 5 p.m.; and concentrate (Equimax Premium - IRCA Nutrição Animal, associated to Equimax Balance - IRCA Nutrição Animal), with 135 $\mathrm{g} / \mathrm{Kg}$ crude protein and $3.970 \mathrm{Kcal} \mathrm{Kg}^{-1}$ ) digestible energy, supplied at $4.0 \mathrm{~kg}$ /day: $1.5 \mathrm{~kg}$ at 6 a.m.; $1.0 \mathrm{~kg}$ at 11 a.m.; $1.5 \mathrm{~kg}$ at 3 p.m.; $60 \mathrm{~g}$ daily of mineral salt (IRCAFÓS EQUOS 72 ADE - IRCA Nutrição Animal) associated with the concentrate, supplied to the animals in the morning; water ad libitum.

Ten Quarter Horse were used in the research, all raised in the same stud farm where the study was carried out. Horses were housed in masonry stalls $4.5 \times 5.0$ meters (m), with floors covered by sawdust, feeder, and automatic water cooler, and were trained once a day from Monday to Friday, generally for two to two and a half hour, in the mornings, performing warm-up and barrel racing. Everyone had been on this training routine for at least a year. They had participated in the last race in January 2016 and remained in training the following month. The study was conducted in March 2016.

The equines were assessed (five animals/ day, on two consecutive mornings): seven males and three mares, five to eight years old (mean age of 7,1), $360-492 \mathrm{~kg}$ body weight (mean weight $=419,60$ ), healthy and adapted to barrel racing test. On the morning of the first day of the study, the temperature before the start of the training was $25^{\circ} \mathrm{C}$ and $30^{\circ} \mathrm{C}$ at the end; and on the second day it was $24^{\circ} \mathrm{C}$ and $30^{\circ} \mathrm{C}$ at the end of training; both days were sunny, but it was the rainy season.

The times (T) of the clinical assessments and the collection of venous blood were performed: at rest, before the start of physical activity (T0); immediately (maximum of three minutes) after a warmup trotting for 10 minutes and then running the barrel racing course twice with a 10 minute interval walking in shade in a covered location (T1); and after one hour's rest, held by the halter and kept in a shaded place (T2).

The training of barreling was carried out in a similar way with that used in competition of this modality: on soft and terrain, three barrels were positioned to form a triangle. The barrels 1 and 2 formed the base of the triangle and were $27.5 \mathrm{~m}$ equidistant. The barrel 3, positioned as the top of the triangle, was $32.0 \mathrm{~m}$ away from each of the other barrels. The start-finish line was demarcated parallel to an imaginary line between the drums 1 and 2, at 
$18.30 \mathrm{~m}$ from these, in the opposite direction to the tip of the triangle. On each course the horse and knight sets bypassed the first drum in a $360^{\circ}$ turn from left to right, then the second and third also by $360^{\circ}$, but from right to left, and then headed for the finish line. In each course the horse-rider sets rounded the first drum in a $360^{\circ}$ turn from left to right, then the second and third also $360^{\circ}$, but from right to left, and headed for the line arrival, and after this, they immediately proceeded to a covered sand area next to the runway for procedures for evaluating the animals and collecting the samples.

Clinical parameters such as heart rate, respiratory rate, mucosal staining and humidity, capillary filling time, rectal temperature, absence of pain and inappetence, and laboratory tests such as hematocrit, glycemia and proteinemia were evaluated. All ten animals had these normal parameters. In T1, heart and respiratory rate were evaluated for one minute immediately (between 15 and 20 seconds) after the second course, and the rectal temperature for three minutes (SPEIRS, 1997).

The hemogasometry was assessed using blood samples collected anaerobically, after skin antisepsis, by puncturing the jugular vein with a 30x7 needle in previously heparinized $3 \mathrm{~mL}$ disposable plastic syringes. After collection, a small quantity of blood from each animal was immediately placed individually in a cartridge model CG4+ (cartridge for hemogasometry - Abaxiz Brasil) in the hemogasometry apparatus (I-STAT - Abaxis Brasil) to obtain the following hemogasometric parameters: hydrogenionic potential $(\mathrm{pH})$, plasma bicarbonate concentration $\left(\mathrm{HCO}_{3}^{-}\right)$, partial carbon dioxide pressure $\left(\mathrm{pCO}_{2}\right)$, base titratable concentration (cBase), total carbon dioxide concentration $\left(\mathrm{tCO}_{2}\right)$, partial oxygen pressure $\left(\mathrm{pO}_{2}\right)$ and oxyhemoglobin saturation $\left(\mathrm{SO}_{2}\right)$.

Blood samples were collected, after skin antisepsis, by puncturing the jugular vein, placed in flask containing sodium fluoride to obtain plasma (vacuum siliconized flask - $4.0 \mathrm{ml}$ - sodium fluoride - Vacuette), and in siliconized flasks without anticoagulant to obtain serum (vacuum siliconized flask - $4.0 \mathrm{ml}$ without anticoagulant - Vacuette). The serum and plasma aliquots were kept frozen at $-20{ }^{\circ} \mathrm{C}$ until the time of the laboratory analyses, at the Laboratory of Clinical Analyses at the Federal University of Viçosa, State of Minas Gerais, Brazil. The following were measured in the serum: concentrations ([ ]) of the sodium ions $\left(\mathrm{Na}^{+}\right)$and potassium ions $\left(\mathrm{K}^{+}\right)$by flame photometry (B462 Flame Photometer Micronal, São Paulo, Brazil).
Serum chloride $\left(\mathrm{Cl}^{-}\right)$and plasma lactate $\left(\mathrm{Lac}^{-}\right)$ were determined by biochemical multi analyzer (HumanStar 300; Human GmbH, Wesbaden, DEU).

After obtaining the ion values, the strong ion differences (SID) were calculated by the formula: $\mathrm{SID}(\mathrm{mEq} \mathrm{L}-1)=\left(\left[\mathrm{Na}^{+}\right]+\left[\mathrm{K}^{+}\right]\right)-\left(\left[\mathrm{Cl}^{-}\right]+\left[\mathrm{Lac}^{-}\right]\right)$, and the lactate was included in the SID calculation because during the anaerobiose mechanism in intense exercises lactate can accumulate in the muscle fiber in large concentrations, and also in the blood, therefore it should not be omitted from the SID calculation (LINDINGER, 2004). The anion gap (AG) was calculated by the formula: $\mathrm{AG}\left(\mathrm{mEq} \mathrm{L} \mathrm{L}^{-1}\right)=\left(\left[\mathrm{Na}^{+}\right]\right.$ $\left.+\left[\mathrm{K}^{+}\right]\right)-\left(\left[\mathrm{Cl}^{-}\right]+\left[\mathrm{HCO}_{3}^{-}\right]\right)(\mathrm{CONSTABLE}, 2000$; SCHÜCK e MATOUSOVIC, 2005). The plasma bicarbonate concentration $\left(\left[\mathrm{HCO}_{3}^{-}\right]\right)$obtained in the hemogasometry was used in the anion gap calculation.

In the statistical analysis, a completely randomized block design was used with three treatments (T0, T1. T2) in 10 replications (number of animals). The data for the variables studied were submitted to the test of normality. The normal data and the data normalized by mathematical transformations (logarithmic and arco seno), were submitted to ANOVA and the Tukey test at 5\% probability. The analyses were made using program statistical analysis software (Statistical Analysis System Institute 2015 SAS INSTITUTE SAS/STAT - EUA).

The research was approved by the Ethics Commission on Animal Experimentation - CEEA of the Veterinary Medicine Course at the State University of Maranhão, Brazil - UEMA, protocol number 10/2016.

\section{RESULTS AND DISCUSSION}

According to the results shown in Tables 1, 2 and 3 , the values obtained at the rest time (T0) for all parameters studied were in the range of normality for animals of the equine species. Hematological and biochemical values evaluated before exercise (T0) were within normal limits, and the following mean values and standard deviations were reported: Total Erythrocyte Count (TEC): $7.285 \pm 0.75 \times 10^{6}$; Hemoglobin (Hg): $11.70 \pm 1.35 \mathrm{~g} \mathrm{dL}^{-1}$; Glomerular Volume (VG \%): 33.60 \pm 2.88 ; total plasma proteins $7.55 \pm 0.31 \mathrm{mg} \mathrm{dL}{ }^{-1}$; Glucose $78.80 \pm 6.71 \mathrm{mg} \mathrm{dL}-1$; Creatinine (Cre): $1.41 \pm 0.17 \mathrm{mg} \mathrm{dL}^{-1}$; Blood Urea Nitrogen (BUN): $34.70 \pm 7.45 \mathrm{mg} \mathrm{dL}^{-1}$; Sodium (Na): 136.40 $\pm 2.86 \mathrm{mMol} \mathrm{L}^{-1}$; Chloride $(\mathrm{Cl})$ : $98.90 \pm 3.75$ mMol L ${ }^{-1}$; Potassium $(\mathrm{K})$ : 3,78 $\pm 0,21 \mathrm{mMol} \mathrm{L}^{-1}$; Total Calcium (tCa) $2.99 \pm 0.26 \mathrm{mMol} \mathrm{L}^{-1}$; Creatine Kinase (CK): $110.00 \pm 20.95$ UI L L $^{-1}$ Aspartate 
Table 1 - Mean values and standard deviations of the $\mathrm{pH}$ (hydrogenionic potential), $\mathrm{HCO}_{3}{ }^{-}$(bicarbonate concentration), cBase (titrable base concentration), and $\mathrm{pCO}_{2}$ (partial carbon dioxide pressure) in venous blood of Quarter Horse in barrel racing training.

\begin{tabular}{|c|c|c|c|c|}
\hline \multirow{3}{*}{ Time } & & & & \\
\hline & $\mathrm{pH}$ & $\mathrm{HCO}_{3}{ }^{-}$ & $\mathrm{pCO}_{2}$ & cBase \\
\hline & $\left(7.31-7.45 \mathrm{mMol} \mathrm{L}^{-1}\right)^{*}$ & $\left(24-30 \mathrm{mMol} \mathrm{L}^{-1}\right)$ & $(41-53 \mathrm{mmHg})$ & $-4-+4$ \\
\hline T0 & $7.39^{\mathrm{a}} \pm 0.02$ & $27.43^{\mathrm{a}} \pm 1.80$ & $45.62^{a} \pm 2.04$ & $2.50^{a} \pm 2.17$ \\
\hline $\mathrm{T} 1$ & $7.06^{\mathrm{b}} \pm 0.10$ & $9.40^{b} \pm 1.97$ & $32.22^{c} \pm 4.53$ & $-20.60^{b} \pm 3.13$ \\
\hline $\mathrm{T} 2$ & $7.37^{\mathrm{a}} \pm 0.03$ & $22.72^{\mathrm{a}} \pm 2.61$ & $38.76^{b} \pm 3.43$ & $-2.60^{\mathrm{a}} \pm 2.88$ \\
\hline
\end{tabular}

Assessment time (T): T0 (before the start of training); T1 (immediately after 10 minutes warmup followed by two courses, at 10 minutes intervals); T2 (one hour resting after T1); "Normal values in venous blood for horses at rest (KANEKO et al., 2008; CASTRO \& GONZALEZ, 2015). Different letters in the same column indicate the different values $(\mathrm{P}<0.05)$ by the Tukey test.

Aminotransferase (AST): $245.20 \pm 61.56 \mathrm{UI} \mathrm{L}^{-1}$. There was no variation of the parameters between males and females nor between the days of study.

Immediately after exercise (T1) there was a concomitant decrease in the $\mathrm{pH}$ values (acidemia), and in the $\mathrm{HCO}_{3}^{-}$and $\mathrm{pCO}_{2}$ concentrations (Table 1 ), that were different from those measured at $\mathrm{T} 0$ $(\mathrm{P}<0.05)$. The decrease in $\mathrm{pH}, \mathrm{HCO}_{3}^{-}$and $\mathrm{pCO}_{2}$ was classified as metabolic acidosis and decreased $\mathrm{HCO}_{3}^{-}$concentration results from the increase in the $\mathrm{H}^{+}$concentration (that decreases the $\mathrm{pH}$ ). As a compensatory physiological response in an attempt to return to the normal $\mathrm{pH}$ is to eliminate carbon dioxide $\left(\mathrm{CO}_{2}\right)$ by pulmonary ventilation, decreasing the blood $\mathrm{pCO}_{2}$ concentration (MARLIN \& NANKERVIS, 2002; CARLOTTI, 2012). Similar results were reported by SILVA et al. (2013) and BARBOSA et al. (2016) who observed reduced $\mathrm{pH}$ and $\mathrm{HCO}_{3}^{-}$in horses due to the lactic acid increased in function of anaerobic exercise (post exercise metabolic acidosis).
The increase in lactic acid at T1 and T2 may be justified by the presence of post-exercise lactate increase (Table 2). However; although, lactic acidosis has been approached for years as a metabolic process in which $\mathrm{H}^{+}$is released and lactate is the end product, which has been considered the cause of muscle fatigue during exercise, there are counterpoints that disagree with this cause-effect relationship. ROBERGS et al. (2004) stated that the proton balance in the muscle cell occurred as a function of the phosphogenic, glycolytic and mitochondrial respiration energy system in the production of cellular ATP. When the demand for ATP in muscle contraction is met by mitochondrial respiration, there is no proton accumulation in the cell, as the protons are used by mitochondria for oxidative phosphorylation and maintaining the proton gradient in the membrane. As exercise becomes more intense, the need for ATP regeneration of glycolysis and the phosphogenic system increases to meet the demand for muscle contraction. But in glycolysis; although,

Table 2 - Mean values and standard deviations of $\mathrm{tCO}_{2}$ (total carbon dioxide concentration, $\mathrm{pO}_{2}$ (partial oxygen pressure, sO (oxihemoglobina saturation), and lactate in venous blood of Quarter Horse in barrel racing training.

\begin{tabular}{ccccc}
\hline Time & \multicolumn{1}{c}{$\mathrm{CCO}_{2}$} & $\mathrm{sO}_{2}$ & Lactate \\
& $\left(28-35 \mathrm{mMol} \mathrm{L}^{-1}\right)^{*}$ & $(35-40 \mathrm{mmHg})$ & $(26-74 \%)$ & $\left(0.5-1.5 \mathrm{mMol} \mathrm{L}^{-1}\right)$ \\
$\mathrm{T} 0$ & $28.80^{\mathrm{a}} \pm 1.81$ & $32.6^{\mathrm{b}} \pm 3.7$ & $61.1^{\mathrm{a}} \pm 6.4$ & $0.82^{\mathrm{c}} \pm 0.12$ \\
$\mathrm{~T} 1$ & $10.40^{\mathrm{b}} \pm 1.96$ & $48.2^{\mathrm{a}} \pm 5.3$ & $66.8^{\mathrm{a}} \pm 7.6$ & $21.09^{\mathrm{a}} \pm 4.87$ \\
$\mathrm{~T} 2$ & $23.80^{\mathrm{a}} \pm 2.70$ & $35.5^{\mathrm{b}} \pm 3.1$ & $66.3^{\mathrm{a}} \pm 5.5$ & $6.26^{\mathrm{b}} \pm 1.87$ \\
\hline
\end{tabular}

*Normal venous blood values for horses at rest (LINDINGER, 2004; FRANKLIN \& PELOSO, 2006; KANEKO et al., 2008; CASTRO \& GONZALEZ, 2015). Times (T): T0 (before the training start); T1 (immediately after 10 minutes warmup, followed by two courses, at 10 minutes intervals); T2 (one hour resting after T1). Different letters in the same column indicate the different values (P<0.05) by the Tukey test. 
Table 3 - Mean values and standard deviations of heart rate (HR), rectal temperature (RT), strong ion difference (SID) and anion gap (AG) in venous blood of Quarter Horse in barrel racing training.

\begin{tabular}{lcccc}
\hline Time & $\mathrm{HR}$ & $\mathrm{RT}$ & SID & AG \\
& $(28-40 \mathrm{bpm})^{*}$ & $\left(37.5-38.5^{\circ} \mathrm{C}\right)$ & $\left(37-43 \mathrm{mEq} \mathrm{L}^{-1}\right)$ & $\left(5-16 \mathrm{mEq} \mathrm{L}^{-1}\right)$ \\
T0 & $37.60^{\mathrm{c}} \pm 3.37$ & $37.21^{\mathrm{b}} \pm 0.39$ & $40.46^{\mathrm{a}} \pm 2.88$ & $11.97^{\mathrm{c}} \pm 3.93$ \\
T1 & $106.40^{\mathrm{a}} \pm 12.54$ & $39.49^{\mathrm{a}} \pm 0.71$ & $22.33^{\mathrm{b}} \pm 3.05$ & $32.53^{\mathrm{a}} \pm 3.89$ \\
T2 & $50.00^{\mathrm{b}} \pm 8.89$ & $38.86^{\mathrm{a}} \pm 0.80$ & $37.82^{\mathrm{a}} \pm 3.12$ & $19.35^{\mathrm{b}} \pm 3.81$ \\
\hline
\end{tabular}

*Reference values for resting horses (SPIERS, 1999; HINCHCLIFF et al., 2004; LINDINGER, 2004; THRALL, 2004; KANEKO et al., 2008; CASTRO \& GONZALES, 2015). Times (T): T0 (before the training start); T1 (immediately after 10 minutes warmup followed by two courses, at 10 minutes intervals); T2 (one hour resting after T1). Different letters in the same column indicate the different values $(\mathrm{P}<0.05)$ by the Tukey test.

intermediate acid production occurs, no molecule is always in acid form and does not function as a proton source. Thereby, the production of protons released in glycolysis occurs without any metabolic acid production.

Based on the proposal of ROBERGS et al. (2004), the absence of acid production could lead to nonproduction of lactic acid in glycolysis. So where would lactate come from? ROGARTZKI et al. (2015) showed that lactate is formed in the reaction Pyruvate + NADH (Nicotinamide-Adenine-Reduced Dinucleotide) $+\mathrm{H}^{+}$, generating Lactate + NAD (oxidized), catalyzed by the enzyme lactate dehydrogenase, and its accumulation in the cell depends on glycolysis rate, oxidative enzymatic activity, cellular oxygen and net rate of its transport out of the cell. The authors also pointed out that; although, present in an anaerobic process, lactate would always be produced in the presence or lack of oxygen, as oxygen is not limited to oxidative phosphorylation in most cellular conditions, and would be the end product of glycolysis under metabolic conditions.

The reduction in the $\mathrm{HCO}_{3}^{-}$concentration was due to the need of buffering by these increased $\mathrm{H}^{+}$protons (MARLIN \& NANKERVIS, 2002), justifying their reduction at $\mathrm{T} 1$ and without full recomposition to normal concentrations in $\mathrm{T} 2$, which lowered the $\mathrm{pH}$ at T2 (Table 1). Decrease in cBase at $\mathrm{T} 1(\mathrm{P}<0.05)$ may have occurred due to the reduction of $\mathrm{HCO}_{3}^{-}$, because this is the most quantitative and important $\mathrm{H}^{+}$buffer in the organism (CARLOTTI, 2012), confirming that the variation in the cBase can accompany the $\mathrm{HCO}_{3}^{-}$direction variation in horses after exercise (KUPCZYNSKI e SPITALNIAK, 2015; LINHARES et al., 2017).

Decrease in $\mathrm{pH}, \mathrm{HCO}_{3}^{-}$and cBase with concomitant reduction in $\mathrm{pCO}_{2}$ reinforced the occurrence of metabolic acidosis in the present study, corroborating the studies by SILVA et al. (2009) who also reported decrease in these parameters in the venous blood of horses after submitting them to maximum exercise on a treadmill. The decrease in these parameters reaffirms the effect of lactic acid diffusion in the blood originating from the muscle cells under the predominance of the anaerobic glucose metabolism, causing lactic acidosis (MARLIN \& NANKERVIS, 2002; BARBOSA et al., 2016; LINHARES et al., 2017).

The reduction in the $\mathrm{pCO}_{2}$ value after exercise (T1), corroborates the study by SILVA et al. (2013) who also reported this response in Quarter Horse at the end of barrel racing. At $\mathrm{T} 2$, the $\mathrm{pCO}_{2}$ had not yet been restored $(\mathrm{P}<0.05)$; although, the $\mathrm{pH}$ was already recomposed (Table 1). It can be inferred from the results at the respective times that reduction in $\mathrm{pCO}_{2}$ participated in reducing metabolic acidosis through hyperventilation imposed by the respiratory or pulmonary control as a compensatory response, considered a defense mechanism when there is variation in $\mathrm{H}^{+}$on the bulb, that starts minutes after an acid base alteration (FURONI et al., 2010).

Although, reduced in $\mathrm{T} 1, \mathrm{pCO}_{2}$ was close to the minimum normal limit, when there was only a small reduction in $\mathrm{HCO}_{3}^{-}$, and $\mathrm{pH}$ was normal, signaling the occurrence of simple metabolic acidosis, which occurs when the decrease in $\mathrm{pCO}_{2}$ is small or non-existent in the presence of $\mathrm{H}^{+}$and $\mathrm{HCO}_{3}^{-}$reduction (THRALL, 2004). However, the cBase increased at $\mathrm{T} 1$ post exercise $(\mathrm{P}<0.05)$, reaching -20.60 (Table 1), a high value compared to the normal, but at T2 it was close to the base values or $\mathrm{T} 1$ ( $\mathrm{P}>0.05)$. Thus, it is coherent to consider that the metabolic acidosis was transient. 
Shortly after exercise (T1), the $\mathrm{tCO}_{2}$ concentration decreased $(\mathrm{P}<0.05)$ in relation to $\mathrm{T} 0$, and just like bicarbonate, was still not fully recomposed to normal concentrations in T2 (Table 2). Decrease in $\mathrm{tCO}_{2}$ is expected when there is decrease in the $\mathrm{HCO}_{3}^{-}$concentration, because a large part of $\mathrm{CO}_{2}$ is transported in the form of $\mathrm{HCO}_{3}^{-}$. Its variations are directly related both to arterial and vein blood (SUCUPIRA \& ORTOLANI, 2003), as observed in the assessment of this parameter in the venous blood of horses in the present study.

The exercise increased the $\mathrm{pO}_{2}(\mathrm{P}<0.05)$ at T1. SILVA et al. (2013) emphasized that increase in $\mathrm{pO}_{2}$ at the end of maximum exercise results from increase in $\mathrm{pCO}_{2}$. However, the $\mathrm{pCO}_{2}$ decreased at $\mathrm{T} 1$; therefore, the results are not in agreement. Conversely, MIRANDA et al. (2016) considered that increase in $\mathrm{pO}_{2}$ results from high $\mathrm{O}_{2}$ absorption.

There was also no significant increase $(\mathrm{P}>0.05)$ at $\mathrm{T} 1$ in the $\mathrm{sO}_{2}$ concentration (Table 3). SILVA et al. (2013) also reported no increase in $\mathrm{SO}_{2}$ in horses at the end of maximum exercise and emphasized that increase in $\mathrm{pH}$ promotes larger hemoglobin and oxygen affinity, leading to bigger saturation and increase in the $\mathrm{sO}_{2}$ rate. However, the increase in the $\mathrm{pO}_{2}$ after effort may have contributed to the $\mathrm{sO}_{2}$ not varying at the time studied, the bigger oxygen affinity for hemoglobin occurs with increase in $\mathrm{pO}_{2}$ reported and justified by MIRANDA et al. (2016) when assessing horses under intense exercise on a treadmill. At $\mathrm{T} 2$, the $\mathrm{pO}_{2}$ e $\mathrm{sO}_{2}$ values were restored to their base levels, due to rest (Table 2).

The normal concentration of lactate in the blood of resting horses is 0.5 to $1.5 \mathrm{mMol} \mathrm{L}^{-1}$ (LINDINGER, 2004). Hyperlactatemia is identified as a moderate rise of lactate to levels of $2-5 \mathrm{mMol}$ $\mathrm{L}^{-1}$ without acidosis, and lactic acidosis occurs at lactate levels $>5 \mathrm{mMol} \mathrm{L}^{-1}$ and results in metabolic acidosis (FRANKLIN \& PELOSO, 2006). The blood lactate concentration increased at $\mathrm{T} 1(\mathrm{P}<0.05)$ (Table 3 ) reaching the limits of hyperlactatemia. Similarly, RODRIGUES et al. (2016) also verified increase of lactate in horses at the end of a simulated barrel racing training. The increase was due to the use of phosphocreatine stock and anaerobic glycolysis for rapid energy production (GOMIDE et al., 2006; PEREIRA et al., 2018), as well as described in Quarter Horse performing barrel racing (BUENO et al., 2012) and Team Ropping test (PEREIRA et al., 2018), which like that of barrel racing, is of high intensity and short duration.

Lactate decreased considerably at $\mathrm{T} 2$ compared to $\mathrm{T} 1(\mathrm{P}<0.05)$, but not enough to reduce the increased lactate level in the blood (hyperlactatemia), that remained higher when compared to $\mathrm{T} 0(\mathrm{P}<0.05)$ and at a value higher than the physiological limit (Table 2). The lactate threshold is a metabolic method that refers to the point of loss of balance between production, use and removal of lactate due to the excess of lactate produced, and the level of lactate begins to rise exponentially in the blood (FERRAZ et al., 2008). Importantly, at the moment of increased proton release during exercise, lactate production also increases, but with important metabolic functions, such as preventing the accumulation of pyruvate and providing the necessary NAD for glycolysis. Therefore, lactate is not considered in this metabolic process as "villain", quite the contrary, it production is important and necessary to avoid triggering early muscle fatigue and loss in exercise performance (ROBERGS et al., 2004).

This result demonstrated that one hour of post exercise rest was not enough time for the lactate to return to the physiological concentrations. However, when the concentrations of T1 $\left(21.09 \mathrm{mMol} \mathrm{L}^{-1}\right)$ and $\mathrm{T} 2\left(6.26 \mathrm{mMol} \mathrm{L}^{-1}\right)$, there was an expressive reduction of approximately $60 \%$ in T2, which may be related to good conditioning of the horse to this activity, since in well-conditioned horses there is a faster reduction in the lactate concentration in post exercise than in those that do not have good conditioning (HODGSON \& ROSE, 1994). Conversely, this may possibly be related to the fact that the study was carried out in an initial period of training and competitions (March 2016); although, all the horses in the study were already from competitions. Therefore, it is probable that with a training activity and more frequent tests during the course of the year, a better adaptation could gradually improve the conditioning of the animals and; consequently, their responses of synthesis and recomposition of lactate to the normal limits more quickly after the courses.

Another parameter used to infer the intensity of exercise is heart rate (HR), widely accepted as an indicator of cardiovascular function, being very correlated with oxygen consumption and blood lactate concentration (MUKAI et al., 2007). In the present study, the HR in T2 was higher than in $\mathrm{T} 1(\mathrm{P}<0.05)$; and although, already well reduced and close to the basal mean, it still remained larger than at T0 and not completely stabilized $(\mathrm{P}<0,05)$ after rest (Table 3), as occurred similarly to lactate.

According to MUKAI et al. (2007), lactate variation, a cost in ventilation, and increase in temperature due to strenuous muscular effort may influence HR response. These factors may have been 
very influential for HR results in the present study, justified by the variations found in lactate, $\mathrm{pCO}_{2}$, $\mathrm{pO}_{2}$ and $\mathrm{sO}_{2}$, and also in the rectal temperature that increased after exercise $(\mathrm{P}<0.05)$ and still remained increased after rest for one hour $(\mathrm{P}<0.05)$, as shown in table 3.

The SID decreased at T1 compared to T0 $(\mathrm{P}<0.05)$ and returned to the physiological limits at T2 (Table 3). According to CONSTABLE (2000), alterations in the strong or weak ions in the body can also affect the $\mathrm{ABB}$, based on the principle of electroneutrality that considers that the sum of all the positive charges (cations) is equal to the sum of all the negative charges (anions). These alterations have been determined by calculating the difference in strong ions (SID) and anion gap (AG), even assessing horses in different sporting activities (LINDINGER, 2004).

The main strong cations in the blood are sodium $\left(\mathrm{Na}^{+}\right)$and potassium $\left(\mathrm{K}^{+}\right)$, and the anions include chloride $\left(\mathrm{Cl}^{-}\right)$, but also lactate when there is possible increase in this anion, especially regarding intense muscular activity (LINDINGER, 2004). The $\mathrm{Na}, \mathrm{K}$ and $\mathrm{Cl}$ concentration remained at normal values at the three times studied and did not differ between the times. However, the lactate concentration increased between the four ions at $\mathrm{T} 1$ and $\mathrm{T} 2(\mathrm{P}<0.05)$ and was the cause of decrease in the SID (Table 3 ).

The low SID at $\mathrm{T} 1 \quad(\mathrm{P}<0.05)$ confirmed the presence of metabolic acidosis that can result from decreased strong cation or increased strong anion concentrations, and in the present case, there was increase in the lactate anion (SCHÜCK \& MATOUSOVIC, 2005).

AG increased at $\mathrm{T} 1$ compared to $\mathrm{T} 0$ $(\mathrm{P}<0.05)$ and had not yet been recomposed at $\mathrm{T} 2$, when it remained bigger than the basal $\mathrm{T} 0$ but smaller than at T1 (Table 3). Similar results were obtained by SILVA et al. (2009) who observed increase in AG immediately after exercise in horses submitted to maximum exercise, and that remained increased 30 minutes after the effort. These authors attributed the $A G$ increase to decrease in the bicarbonate concentration during its buffering action on the lactic acidosis. Similarly, the AG increased just after the end of the second course and was still increased up to one hour after rest (Table 1).

According to CARLOTTI (2012), increased plasma AG gap values indicate the presence of one or more anions not commonly measured in the plasma. In patients with metabolic acidosis, $\mathrm{H}^{+}$ reacts with $\mathrm{HCO}_{3}{ }_{3}^{-}$and consequently there is a fall in the $\mathrm{HCO}_{3}^{-}$plasma concentration, that is replaced by the lactate anion, that causes increase in the anion gap. Hence it can be considered that the increase in the plasma lactate concentration was the influencing anion gap for the AG increase in the horses at the two times studied after two barrel racing training. Increase in the lactate blood concentration of over $5 \mathrm{mMol}$ $\mathrm{L}^{-1}$ with concomitant increase in $\mathrm{AG}$ and $\mathrm{pH}<7.3$ was characteristic of lactic acidosis (CHARLES \& HEILMAN, 2005), as was observed in the results of the present study (Tables 1, 2 and 3).

\section{CONCLUSION}

After two training course in barrel racing, the Quarter Horses adapted to this type of equestrian race presented metabolic acidosis and hyperlactatemia. One hour of rest after the second course was enough to remove the acidemia, but not to restore the ABB completely from the effects of post exercise lactic acidosis, as the $\mathrm{HCO}_{3}^{-}$, $\mathrm{pCO}_{2}, \mathrm{tCO}_{2}$ and $\mathrm{AG}$, and hyperlactatemia was still present after the rest for an hour.

\section{ACKNOWLEDGEMENTS}

The authors are grateful the: Fundação de Amparo à Pesquisa e ao Desenvolvimento Científico e Tecnológico do Maranhão (FAPEMA), Maranhão, Brazil, for funding research grants for ALVES, A.M. (FAPEMA-BIC 02415/15) and FUCUTA, R.S, (FAPEMA-BIC 04190/16); Coordenação de Aperfeiçoamento de Pessoal de Nível Superior (CAPES), Brazil, for partial financing - Finance code 001; To Haras Quatro Irmãos, Maranhão, for granting the location and the horses for the animal experiment; Laboratório de Patologia Clínica Veterinária (LPCV) of the UEMA, Maranhão, Brazil and Laboratório de Pesquisa em Patologia Clínica Veterinária (LPPCV) of the Universidade Federal de Viçosa (UFV), Minas Gerais, Brazil, for carrying out the laboratory analyzes.

\section{BIOETHICS AND BIOSSECURITY COMMITTEE APPROVAL}

The research was approved by the Ethics Commission on Animal Experimentation - CEEA of the Veterinary Medicine Course at the State University of Maranhão, State of Maranhão, Brazil., protocol number 10/2016.

\section{DECLARATION OF CONFLICT OF INTERESTS}

The authors declare no conflict of interest. The founding sponsors had no role in the design of the study; in the collection, analyses, or interpretation of data; in the writing of the manuscript, and in the decision to publish the results.

\section{AUTHORS' CONTRIBUTIONS}

GOMES, C.L.N. designed, supervised and coordinated the animal experiment, performed the experiment, provided clinical data and carried out the laboratory analyses.

Ciência Rural, v.50, n.5, 2020. 
ALVES, A.M. and FUCUTA, R.S., performed the experiment provided clinical data and carried out the laboratory analyses. ARANHA, R.M.C.A performed the experiment and provided clinical data. RIBEIRO FILHO, J.D. and RIBEIRO, B.M. carried out the laboratory analyses. MORAES JUNIOR, F.M performed statistical analyses of experimental data. GOMES, C.L.N., RIBEIRO FILHO, J.D., CHAVES, R.M., ALVES, A.M. and FUCUTA, R.S. contributed for the conception and writing of the manuscript. All authors critically revised the manuscript and approved of the final version.

\section{REFERENCES}

BARBOSA, J.P.B. et al. Endoscopic airway, blood gas, electrolytes, and acid-base in equine submitted to three-barrel training. Arquivo Brasileiro de Medicina Veterinária e Zootecnia, v.68, n.5, p.1152-1158, 2016. Available from: <http://www.scielo.br/scielo. php?pid=S0102-9352016000501152\&script =sciabstract\&tlng= ptt>. Accessed: Mar. 07, 2018. doi: 10.1590/1678-4162-8739.

BAYLY, W.; KLINE, K.A. Hematología e bioquímica. In: BOFFI, F.M. Fisiologia del Ejercicio em Equinos. Buenos Aires : Intermédica, 2007. Cap.10, p.145-151

BUENO, G.M. et al. Curva lactacidêmica em equinos da raça Quarto-de-milha durante a realização da prova dos Três Tambores. Revista de Educação Continuada em Medicina Veterinária e Zootecnia do CRMV-SP, v.10, n.1, p.80-81, 2012. Available from: <https://www.revistamvez-crmvsp.com.br/index.php/ recmvz/article/vie/335/306>. Accessed: Feb. 09, 2019.

CAIADO, J. C. C. et al. Influence of physical exercise on serum activities of AST and CK and plasma concentration of lactate in Quarter horses submitted to team roping. Pesquisa Veterinária Brasileira, v.31, n.5, p.452-458, 2011. Available from: <http:// www.scielo.br/pdf/pvb/v31n5/v31n5a14.pdf>. Accessed: Feb. 24, 2020.

CARLOTTI, A.P.C.P. Abordagem clínica dos distúrbios do equilíbrio ácido-base. Medicina, v.45, n.2, p.244-62, 2012. Available from: <http://revista.fmrp.usp.br/2012/vol45n2/Simp9 Abordagem $\% 20 \mathrm{cl} \%$ EDnica $\% 20$ dos $\% 20$ dist $\%$ FArbios $\% 20$ do $\% 20$ equil $\%$ EDbrio\%20\%E1cido-base.pdf>. Accessed: Mar. 10, 2018.

CASTRO, T.F.; GONZÁLEZ, F. Blood gas analysis in Mangalarga Marchador horses with colic. Revista MVZ Córdoba, v.20, p.4447-4454, 2015. Available from: <http://www.scielo.org.co/ pdf/mvz/v20n1/v20n1a07.pdf>. Accessed: Jul. 06, 2017.

CHARLES, J.C.; HEILMAN, R.L. Metabolic Acidosis. Hospital Physician, v.1, p.37-42, 2005. Available from: <http://www. turner-white.com $/$ memberfile.php?PubCode $=\mathrm{hp} \_$mar05_acid. pdf $>$. Accessed: Mar.05, 2014.

CONSTABLE, P.D. Clinical Assessment of acid-base status: Comparison of the Henderson-Hasselbalch and strong ion approaches. Veterinary Clinical Pathology, v.29, n.4, p.115-128, 2000. Available from: $<$ https://doi.org/10.1111/j.1939-165X.2000. tb00241.x.>. Accessed: Jan. 08, 2012. doi: 10.1111/j.1939165X.2000.tb00241.x.

DOS SANTOS, G.B. Lactato: De vilão a mocinho. Revista Brasileira de Nutrição Funcional, v.42, n.77, p.23-30, 2019. Available from: <https://www.researchgate.net332047139 lactato_De_vilão_a_mocinho. Accessed: Nov. 18, 2019, doi: $10.32809 / 2176-4522.42 .77 .04$.
FERGUSON, B.S. et al. Lactate metabolism: historical context, prior misinterpretations, and current understanding. European Journal of Applied Physiology, v.118, n.4, p.691-728, 2018. Available from: <https://www.ncbi.nlm.nih.gov_> pubmed $>$. Accessed: Nov. 21, 2019. doi: 10.1007/s00421-017-3795-6.

FERRAZ, G.C. et al. Blood lactate threshold reflects glucose responses in horses submitted to incremental exercise test. Arquivo Brasileiro de Medicina Veterinária e Zootecnia, v.60, n.1, p.256-259, 2008. Available from: <https://www.researchgate. net/publication/232678622_Blood_lactate_threshold_reflects_ glucose responses in horses submittedto incremental exercise_test $>$. Accessed: Nov. $\overline{20}, 2014$, doi: $\overline{10.1590 / \mathrm{S} 0102-}$ $0935200800010003>$.

FERRAZ, G. C. et al. Influência do treinamento aeróbio sobre o cortisol e glicose plasmáticos em equinos. Arquivo Brasileiro de Medicina Veterinária e Zootecnia, v.62, n.1, p.23-29, 2010. Available from: $<$ http://www.scielo.br/scielo.php?script $=$ sci abstract\&pid $=$ S0102-09352010000100003\&lng $=$ pt\&nrm $=$ is o\&tlng $=\mathrm{pt}>$. Accessed: Nov. 19, 2014 . doi: 10.1590/S010209352010000100003 .

FRANKLIN, R.P.; PELOSO, J.G. Review of the Clinical Use of Lactate. AAEP proceedings, v.52, p.305-309, 2006. Available from: < https://pdfs.semanticscholar.org/bdbd/63eda0f8a58ccf9a0 77a25911a615b1a8a9b.pdf>. Accessed: Feb. 08, 2019.

FURONI, R. M.et al. Distúrbios do equilíbrio ácido-base. Revista da Faculdade de Ciências Médicas, v.12, n.1, p.512, 2010. Available from: <https://www.researchgate. net/ publication/277161920_Disturbios_do_equilibrio_acido-basico>. Accessed: Aug. 30, 2016.

GOMIDE, L.M.W. et al. Concentrações sangüíneas de lactato em eqüinos durante a prova de fundo do concurso completo de equitação. Ciência Rural, v.36, n.2, p.509-513, 2006. Available from: <http:// www.scielo.br/pdf/pvb/v38n9/1678-5150-pvb-38-09-1856.pdf $>$. Accessed: Feb. 08, 2012. doi: 10.1590/1678-5150-PVB-5449.

HINCHCLIFF, K.W. et al. Equine sports medicine and surgery: basic and clinical of the equine athlete. Philadelphia: W.B. Saunders, 2004, 1364p.

HODGSON, D.R.; ROSE, R.J. The athletic horse: principles and practice of equine sports medicine. Philadelphia : Saunders, 1994. 497p.

KANEKO, J.J. et al. Clinical Biochemistry of Domestic Animals. 6.ed. San Diego : Academic Press, 2008, 928p.

KUPCZYNSKI, R.; SPITALNIAK, K. Analysis of acid-base balance as well as hematological and biochemical parameters in horses of combined driving discipline. Archives Animal Breeding, n.58, p.221-228, 2015. Available from: $<$ https://www. arch-anim-breed.net/58/221/2015/>. Accessed: Set.09, 2017. doi: 10.5194/aab-58-221-2015.

LINDINGER M.I. Acid-base physiology during exercise and in response to training. In: HINCHCLIFF, K.W. et al. Equine Sports Medicine and Surgery. Philadelphia : SAUNDERS, 2004. Cap.39, p.872-897.

LINHARES, J.M. et al. Pheysical exercise on serum electrolytes and acid base balance in Mangalarga Marchador horses submitted to cavalcade of 4, 8 and $20 \mathrm{~km}$. Ciência Rural, v.47, n.5, p.1-6, 
2017. Available from: <http://www.scielo.br/scielo.php?script= sci_arttext\&pid=S0103-84782017000500601>. Accessed: Mar. 05, 2018. doi: 10.1590/0103-8478cr20160277.

MARLIN, D.; NARKERVIS, K.J. Equine exercise physiology. Oxford: Wiley-Blackwell, 2002. 304p.

MIRANDA, A.C.T. et al. Hemogasometry of eventing horses before and after intense exercise on a high speed treadmill. Livestock Science, v.186, p.85-87, 2016. Available from: $<$ https:// www.sciencedirect.com/science/article/pii/S1871141315003583>. Accessed: Jun. 08, 2017. doi: 10.1016/j.livsci.2015.07.020.

MUKAI, K. et al. Heart rates and blood lactate response in throughbreed horse during race. Journal Equine Science, v.18, n.4, p.153-160, 2007. Available from: $<$ https://www.researchgate.net/publication/248394785 Heart Rates and Blood Lactate Response in Thoroughbred Horses_during_a_Race> Accessed: Feb. 08, 2019.

NIELSEN, F.H.; LUKASKI, H.C. Update on the relationship between magnesium and exercise. Magnesium Research, v.19, n.3, p.180-189, 2006. Available from: <https://pdfs. semanticscholar.org/b6d9/2239319f5b166686200fl feb3ccc805de 78d.pdf.>. Accessed: Jun. 15, 2017.

PEREIRA, M.S. et al. Avaliação da lactatemia e das enzimas musculares de equinos Quarto de Milha submetidos à prova de laço em dupla com diferentes tipos de treinamento. Pesquisa Veterinária Brasileira, v.38, n.9, p.1856-1862, 2018. Available from: $<\mathrm{http}: / /$ www.scielo.br/scielo.php?script=sci abstract\&pid=S0100-736X2018000901856\&lng=en\&nrm=iso\& tlng $=\mathrm{pt}>$. Accessed: Feb. 10, 2019.

ROBERGS, R. A. Biochemistry of exercise-induced metabolic acidosis. American Journal of Physiology, Regulatory, Integrative e Comparative Physiology, v.287, p.502516, 2004. Available from: <www.physiology.org/journal/ ajprega(045.071.006.013)>. Accessed: Nov. 20, 2019. doi: 10.1152/ajpregu.00114.2004.

RODRIGUES, I.M.S.M.M. et al. Perfil bioquímico e oxidativo de cavalos usados em prova simulada dos três tambores. Revista Brasileira de Medicina Veterinária, v.38, n.2, p.93100, 2016. Available from: <rbmv.org/index.php/BJVM/article/ download/200/130/>. Accessed: Mar. 28, 2017.

ROGATZKI, M.J. et al. Lactate is always the end product of glycolysis. Frontiers in Neuroscience, v.9, p.1-7, 2015. Available from: <https://www.researchgate.net_> publication_>_2736386>. Accessed: Nov. 21, 2019. doi: 10,3389/fnins.2015.00022.

ROSE, R.J. Problems of the Performance and Endurance Horse: Fluid, Electrolyte and Acid-Base Disturbances Associated with Exercise. In: ROBINSON, E. Current Therapy in Equine Medicine 2. Philadelphia: Saunders, 1987, Cap. 12, p.479-481.

SAS INSTITUTE SAS/STAT. Software changes and enhancements trhough release 9.4. Care : EUA, 2015.

SCHÜCK, O.; M ATOUSOVIC, K. Relation between ph and the Strong ion difference (SID) in body fluids. Biomedical Papers, v.149, n.1, p.69-73, 2005. Available from: <http://citeseerx.ist.psu. edu/viewdoc/download?doi=10.1.1.544.5636\&rep=rep1\&type $=p$ df>. Accessed: Jan. 09, 2014.

SILVA, M.A.G. et al. Equilíbrio ácido-base em equinos da raça Quarto de milha participantes da prova dos Três Tambores. Revista Brasileira Medicina Veterinária, v.35. p.188-192, 2013 Available from: <http://www.rbmv.com.br/pdf_artigos/31-102013_16-25RBMV015.pdf>. Accessed: Oct. 11, 2016.

SILVA, M.A.G. et al. Determinação de eletrólitos, gases sanguíneos, osmolalidade, hematócrito, hemoglobina, base titulável e anion gap no sangue venoso de equinos destreinados submetidos ao exercício máximo e submáximo em esteira rolante. Arquivo Brasileiro de Medicina Veterinária e Zootecnia, v.61, n.5, p.1021-1027, 2009. Available from: <http://www.scielo.br/ pdf/abmvz/v61n5/a02v61n5.pdf>. Accessed: Dec. 08. 2014. doi. org/10.1590/S0102-09352009000500002.

SPEIRS, V. C. Exame Clínico de Eqüinos. Porto Alegre : Artmed, 1999, 366 p.

STRICKLIN, J.B. Barrel Racing. AAEP Proceedings, v.43, p.3739, 1997. Available from: <https:/scielo.conicyt.cl/pdf/amv/v46n3/ art11.pdf>. Accessed: Dec. 17, 2016.

SUCUPIRA, M.C.A.; ORTOLANI, H.L. Uso de sangue arterial e venoso no exame do equilíbrio ácido-básico de novilhos normais ou com acidose metabólica. Ciência Rural, v.33, n.5, p.863-868, 2003. Available from: <http://www.scielo.br/scielo/ php?pid=S0103-8478200>. Accessed: Aug. 13, 2013. doi. org/10.1590/S0103-84782003000500011.

THRALL. M.A. et al. Veterinary hematology and clinical chemistry. Philadelphia: Lippincott Willians and Wilkins, 2004, 518p. 